\title{
SPORTS CELEBRITY AS AN INTERMEDIARY AND CULTURAL INSTRUMENT OF FUNDAMENTAL RIGHTS AND ETHNIC-RACIAL EQUALITY. A STUDY OF THE CORPORATE CAMPAIGN "COMMON THREAD", PUBLISHED BY THE SPORTS BRAND NIKE ON INSTAGRAM
}

\begin{abstract}
JAVIER DÍAZ-BAJO RODRIGUEZ
javier.diazb@edu.uah.es

Ph.D. candidate and Assistant Professor of Audiovisual Communication and Researcher at the University of Alcalá (Spain). Member of the research group Images, Words and Ideas. His research focuses on discursive and narrative practices conducted by corporate brands through digital media.
\end{abstract}

\section{RUT MARTÍNEZ-BORDA}

rut.martinez@uah.es

Professor of Audiovisual Communication and Research Fellow at the University of Alcalá (Spain). Dr Martínez-Borda is a member of the research group Images, Words and Ideas. Her research focuses on human practices supported by digital technologies, audiovisual narratives, videogames and fandom. Her current projects are supported by the Spanish Ministry of Culture and Education. She has been a visiting scholar at the Institute of Education (University of London); University of Westminster in London; University of Delaware in Philadelphia.

Abstract

Corporate brands play a social role through the discourses they broadcast on their social media. The sports celebrity acts as a cultural intermediary and communicating instrument in the value system that the brand brings together in defence of social, cultural and ethnic diversity (Turner, 2004; Erdogan, 1999; Marshall, 1997).

From this perspective, the aim of this proposal is to detect the socio-cultural elements that articulate the discourse constructed by the Nike sports brand in defence of racial and ethnic equality in sport.

Methodologically, the content analysis approach is adopted (Krippendorff, 2013).

The data consists of 3 short films that make up a campaign created by the sports brand Nike called "Common Thread". The criterion for their selection was the discursive projection that the brand emits in favour of socio-cultural equality on Instagram.

In order to define the model of analysis, the classical studies of Greimas (1976) and McCracken (1989) is taken as a starting point.

The results show that the brand manifests itself on social media as a social agent that promotes equality and racial-ethnic rights for the black sports community through sport and culture.

\section{Keywords}

Brand; values; celebrity; discourse; social media.

\section{How to cite this article}

Díaz-Bajo Rodriguez, Javier; Martínez-Borda, Rut. Sports celebrity as an intermediary and cultural instrument of fundamental rights and ethnic-racial equality. A study of the corporate campaign "common thread", published by the sports brand NIKE on Instagram. Janus.net, ejournal of international relations. Thematic dossier International Relations and Social Networks, July 2021. Consulted [online] on date of last visit, https://doi.org/10.26619/16477251.DT21.4 


\title{
SPORTS CELEBRITY AS AN INTERMEDIARY AND CULTURAL INSTRUMENT OF FUNDAMENTAL RIGHTS AND ETHNIC-RACIAL EQUALITY. A STUDY OF THE CORPORATE CAMPAIGN "COMMON THREAD", PUBLISHED BY THE SPORTS BRAND NIKE ON INSTAGRAM
}

\author{
JAVIER DÍAZ-BAJO RODRIGUEZ
}

\author{
RUT MARTÍNEZ-BORDA
}

\section{Introduction}

The most classical sociological contributions have, over the last few decades, delved deeper into the symbolic character and the cultural meaning that underlies consumption practices and the communicative interactions that revolve around this phenomenon (López de Ayala, 2004; Semprini, 1995).

The Nike corporate brand acquires a social function in its own Instagram account, through the discursive broadcasting of values with a social and cultural character. The sports celebrity acts as a mediator and communicating instrument of a symbolic field that has been constructed and distributed by the brand (Turner, 2004; Erdogan, 1999; Marshall, 1997).

From this perspective, the research questions are as follows:

- What are the socio-cultural values underlying the symbolic field constructed by the brand?

- What narrative patterns articulate the discursive instrumentalisation produced by celebrities and athletes?

In order to answer the questions posed by this research, we take as a starting point the classical studies by Greimas (1976) and McCracken (1989). We have initially relied on these two theoretical models to design a methodological strategy that allows us to identify the narratological elements that articulate the discursive emission of sociocultural values.

Finally, we will show, through the results, that the brand manifests itself in social media as a social agent that promotes equality and fundamental rights of black sports communities through sport and culture. 


\subsection{The social function in consumption processes}

The most classic line of sociological research has focused on the symbolic character that underlies the consumption process, from which the structured character of this phenomenon in modern societies can be explained. It has been the more contemporary sociological approach that has accentuated the impact that the cultural meaning of consumption practices generates in the processes of social and individual identity construction of audiences (López de Ayala, 2004). This assertion implies two different perspectives: first, the concept of consumption transcends the utilitarian function expressed by classical economics. And second, the discursive and symbolic exchange that takes place between different social subjects is recognised in this context.

In relation to a symbolic interaction between corporations and the public, Holbrook (2001) postulates that social subjects interact under ideas, images and symbols to reconfigure individual or social identity projects. They use this social interaction to disseminate specific socio-cultural contexts. Thus, postmodern consumption and its communication processes become an activity that transcends the exchange of commercial value. This symbolic meaning that is transferred through the interaction between social agents acquires a new social function that goes in two directions: outwards, constructing a particular cultural world. And inwards, contributing to the construction of the individual concept of self-identity (Elliott, 1998).

In order to delve deeper into this symbolic perspective that characterises the communicative interaction between subjects, we rely on the structuralist approach that defends the analysis of the hidden structures that sustain social action and manifestations. This is why the use of semiology becomes essential in order to highlight these structures that govern the systems of signs and communication.

Based on these approaches, structuralists conceive the communication process as a social practice through which social subjects express themselves and communicate under symbolic parameters. For Baudillard (1976), the leading exponent of this intellectual approach, the consumption of signs, has replaced necessity in modern societies. The practical utility of consumer objects and interaction with corporations has evolved into an immaterial and discursive exchange that acquires a social and cultural character.

This approach is essential to understand the role played by symbolic fields in the communication processes between corporations and publics. If we rely on the perspective offered by López de Ayala (2004), we could postulate the use of a system of signs endowed with social significance by brands and corporations. In this line, advertising or corporate communication is detached from use value, and the consumption process is conceived as a world of representations and cultural signs. From this moment on, consumption and the communication that are produced around this phenomenon have a social function that transcends the economic objectives of companies. The author Bocock puts it in the following terms: "in the postmodern world, consumption serves to establish the sense of identity of who we are", "Consumer goods have become a crucial element in the establishment of meanings, identities and gender roles in postmodern capitalism" (Bocock, 1995: 141). 
This is why corporations play a decisive role in the creation and discursive projection of values, beliefs and ideas associated with a given socio-cultural context.

\subsection{The symbolic discourse of branding}

In relation to this context, corporate brands construct and project cultural symbolic fields. This approach responds, as Semprini points out, to the following convergence: "The modern brand does not belong to the world of commerce but to the world of communication" (Semprini, 1995: 19).

Establishing a global definition that encompasses in depth the object and functions of the brand phenomenon is a truly complex task. In our argument, we are inclined to propose the nature of the brand phenomenon as an instance and semiotic engine that confers meaning and attribution in an ordered, structured and voluntary manner.

In this communicational transition, the corporate brand comes to generate greater freedom of discursive action. Organisations implement a new symbolic and discursive weight to their communication processes. This fact gives the brand a leading role in this mission, as it acquires a social function in the creation and distribution of social and cultural meanings. Therefore, the brand generates a specific universe of meaning that it creates and disseminates discursively.

Consistent with this postulate, it is important for the development of our research to highlight the role of social values as motivational constructs that relate people's beliefs about desirable goals to be achieved over time and according to different contexts. There are deterministic developments that shed light on the relationship between values and individual behaviour, especially when it comes to core values that influence a person's conception of social identity and self-concept (Verplanken \& Holland, 2002).

\subsection{The sports celebrity as a mediator of discourse}

From the above context, we identify the use of sports celebrities as a mediating instrument of a given universe of social and cultural significance.

One area where it is essential to recognise the differentiation of discourse and meanings is through the use of celebrities in sport. David Marshall (1997) argues that in those industries that are associated with celebrities, communicative particularities originate according to the typology of the industry, and, therefore, different types of meanings are also generated. Furthermore, the author also argues that semiotic and discursive rules are generated around the celebrities, produced through diverse systems that privilege different groups of discourses.

The construction of meanings in sports occurs under the influence of certain social values that are considered exemplary. The sports celebrity is a particularly interesting case, because as David Giles (2004) points out, sport is one of the few areas of public and social life that is truly meritocratic. Sports celebrities can prove that they are the best, so their cultural prominence can be seen as deserved. Celebrities represent subjective positions that audiences can adopt or adapt in their formation of social identities. A 
celebrity, then, is an embodiment of a discursive field about norms of individuality and personhood within a culture.

In the same vein, the sports celebrity is a moderator especially articulated by achievement, excellence and transcendence, often explicitly linked to socio-cultural definitions of nationality and ethnicity.

It is precisely in that process whereby a celebrity is mediatised that the most productive social and cultural functions that the celebrity, and his culture, seem to perform today are generated. The fact that the celebrity extends his identity to the public image means that he conducts some kind of social function in relation to audiences. This social function exercised by the brand, and the staging of the celebrity, reveal new aspects of how brands now generate meaning and significance through the media and advertising industries.

\section{Design and method}

\subsection{Methodological approach}

We adopted the content analysis methodology (Krippendorff, 2013) through discourse (Gee, 2014). This technique has allowed us to analyse, structure and objectify the object of study in the different contents (Neuendorf, 2002).

In relation to the methodology provided by Gee (2014), we have used the discourse analysis of the celebrity in certain contents of the Nike brand on Instagram. The most relevant element we have relied on, based on this theoretical approach, is how the discourse has been instrumentalised by the celebrity for the construction and projection of a particular field of socio-cultural significance.

\subsection{Type of analysis}

In order to define the model of analysis, the classical studies of Greimas (Greimas, 1976) and McCracken (McCracken, 1989) are taken as a starting point. In a first phase, we have approached some variables specific to both authors (table 1). In a second phase, we have designed a model of analysis with certain categories that allow us to respond to the objectives of this research (table 2).

Table 1: Analysis model with authors' variables.

\begin{tabular}{|l|l|}
\multicolumn{1}{|c|}{ Greimas model variables (1976) } & \multicolumn{1}{c|}{ McCracken (1989) variables } \\
\hline Subject: actant who desires an object & Culturally constituted world \\
\hline Object: what you wish & Media / advertising \\
\hline Helper: guides the subject & Consumer goods \\
\hline Opponent: oppressive force & \\
\hline Sender: set of facts and motivating forces & \\
\hline Receiver: people who benefit & \\
\hline
\end{tabular}

Source: own compilation. 
To further our objectives, we have synthesised both approaches and defined a model (table 2) that helps us to associate the categories of analysis with the most important thematic units in our object of study:

Table 2. Methodological model design

\begin{tabular}{|c|c|}
\hline Subject: Actant desires an object & Celebrity and black athletes \\
\hline Object: What you want & $\begin{array}{l}\text { Goals and achievements in defence of cultural } \\
\text { equality and diversity }\end{array}$ \\
\hline Helper: Guides the subject & The Nike brand \\
\hline Opponent: Oppressive force & Sociocultural barriers and difficulties \\
\hline $\begin{array}{l}\text { Sender: A set of desired facts or motivating } \\
\text { forces }\end{array}$ & $\begin{array}{l}\text { Achieving fundamental rights and equal } \\
\text { opportunities }\end{array}$ \\
\hline Receiver: Who benefits & Black athletes \\
\hline \multicolumn{2}{|l|}{ Media / Advertising } \\
\hline nt. Ana & of the "Common Threac \\
\hline
\end{tabular}

Source: Prepared by the authors. Created from the approaches of Greimas (1976) and McCracken (1989).

This system allows us to delve deeper into the main narratological elements that articulate the discursive projection in defence of equality and cultural diversity. On the other hand, this system enables us to identify the social meaning transfer process that occurs in the creation of a cultural world determined and discursively articulated by the sports celebrity.

We consider that the transfer of social meaning arises from a culturally constructed world, through six narratological categories and through the Instagram social media.

In relation to these variables, this proposal aims to identify, describe and compare the fields of symbolic signification and socio-cultural values that the brand seeks to project discursively through the staging of celebrities and young black sportsmen and sportswomen.

\section{Data analysis}

Nike's Instagram account has 774 publications created by the brand itself in the last phase of our analysis (December 2020). It is relevant to highlight that the Nike sports brand publishes corporate or advertising content through the section called "Publications". Of all the content created by the brand on its own account since 2011, we have focused on analysing 3 videos that belong to the campaign called "Common Thread". These contents were published by the brand from $17 / 02 / 20$ to $29 / 02 / 20$. The 
main criterion for choosing the sample was the staging of sportsmen or sports celebrities who act as cultural intermediaries and communication tools for the audiovisual content created and published by the brand.

The brand has created a corporate communications campaign to celebrate Black History Month 2019, which is celebrated in some Anglo-Saxon countries such as England and the USA. The athletes featured in the "Common Thread" campaign are celebrities and young black athletes. The athletes come from different sporting areas and diverse socio-cultural backgrounds. The celebrities narrate part of their own life experience to describe those socio-cultural aspects that have an impact on their lives and the communities to which they belong. In the same way, celebrities and athletes tell the way they experience their sport's practice in a given sociocultural context. In all three videos, we can detect the use of recurrent discursive elements that articulate the projection of values to empower equality and ethno-racial diversity. To carry out the analysis, we need to understand the discursive elements involved in the construction of the symbolic field as a system that articulates the message.

The data collection period ran from 1 September 2020 to 31 December 2020. Below, we show the name of the content, the format, the duration, the date of publication on Instagram and the URL where the content is located:

Table 3. Main content data

\begin{tabular}{|c|c|c|c|c|}
\hline Title Content & $\begin{array}{l}\text { Content } \\
\text { format }\end{array}$ & Playback time & $\begin{array}{c}\text { Date of } \\
\text { publication }\end{array}$ & URL \\
\hline $\begin{array}{l}\text { Common Thread I } \\
\text { Episode 1: Ingrid } \\
\text { \& Alex, Narrated } \\
\text { by } \\
\text { Williams }\end{array}$ & Video 1 & $3: 35$ & $\begin{array}{ll}17 & \text { FEBRUARY } \\
\underline{2020} & \end{array}$ & $\begin{array}{l}\text { https://www.instagram.com } \\
\angle \mathrm{p} / \mathrm{B} 8 \mathrm{rO} 4 \mathrm{zgg0Zw/}\end{array}$ \\
\hline $\begin{array}{l}\text { Common Thread I } \\
\text { Episode } 2: \\
\text { Crystal, Debra \& } \\
\text { Kairaba }\end{array}$ & Video 2 & $3: 44$ & $\underline{21}$ FEBRUARY & $\frac{\text { https://www.instagram.com }}{\text { Lp/B81iLqrA1-b/ }}$ \\
\hline $\begin{array}{l}\text { Common Thread I } \\
\text { Episode 3: Vashti, } \\
\text { RunGrl \& Asra }\end{array}$ & Video 3 & $3: 58$ & $\begin{array}{ll}29 & \text { FEBRUARY } \\
\underline{2020} & \end{array}$ & $\begin{array}{l}\text { https://www.instagram.com } \\
\text { Lp/B9KIOD2HHe7/ }\end{array}$ \\
\hline
\end{tabular}

Source: https://www.instagram.com/nike/?hl=es

For this particular project, we have decided to use the QuickTime Player application for the IOS operating system as an analysis tool. This tool allows us to work with text, photographs and video at the same time, and to analyse texts, images and audio simultaneously, without the need to create descriptions. We transcribed the speeches and dialogues that we considered most representative for use in the research results. In this way, we were able to triangulate the extracted data in order to interpret the results in a narrative and conceptual way (Lacasa, Martínez-Borda, \& Méndez, 2013).

Once again, we insist that the approaches to the data, as well as the models of analysis, are interwoven in an integrated way in our interpretation. This is because our aim is to 
explain the keys that articulate, generate and enable the reproduction of a given sociocultural symbolic field through discourse.

\section{Results}

Two questions guide the research presented in this article and the results allow us to answer them. Firstly, we analyse the presence of digital content created and published by the Nike brand on its own Instagram account. Our object of study focuses on the analysis of the three videos belonging to the "Common Thread" campaign. These contents are analysed with the aim of describing and identifying the socio-cultural values that the brand projects in defence of equality during the commemoration of Black History Month 2019, in countries such as England and the U.S. Secondly, the narrative instrumentalisation that projects the sports celebrity as a cultural intermediary is shown.

A first observation of the data shows how the narratives of the short films respond to narratives starring black sportsmen and sportswomen who practice different sports in different socio-cultural environments. We find in the contents a thematic unit that is transversal in the three short films: the practice of sport by black men and women in specific socio-cultural contexts. All the concepts and references used discursively are oriented towards strengthening the equality and unity of black sports communities as a motivational object.

Following our methodological strategy, we contextualise our analysis in the narratological categories: subject, object, helper, opponent, sender and receiver. We find it relevant in relation to our object of study to prioritise the categories that in our opinion have a greater impact on the projected socio-cultural symbolic field: object, sender and receiver.

In this way, we hope to comprehensively reconstruct the narrative patterns that structure the projection of values recurrently in the three contents.

\subsection{Category 1. Object or desire to be achieved: to build a legacy for future generations.}

The need to contextualise the object of achievement projected by the brand through the celebrity makes it necessary to devote a complementary analysis to other communication channels belonging to the brand. In order to understand the social objective to be achieved, there is nothing better than relying on a communication channel that belongs to the corporation at the time of the analysis, in which the specific purpose of the campaign is expressed: 
Thematic dossier - International Relations and Social Networks (July 2021), pp. 44-60 Sports celebrity as an intermediary and cultural instrument of fundamental rights and ethnic-racial equality. Javier Díaz-Bajo Rodriguez, Rut Martínez-Borda

Figure 1: Nike Campaign - United by a common thread

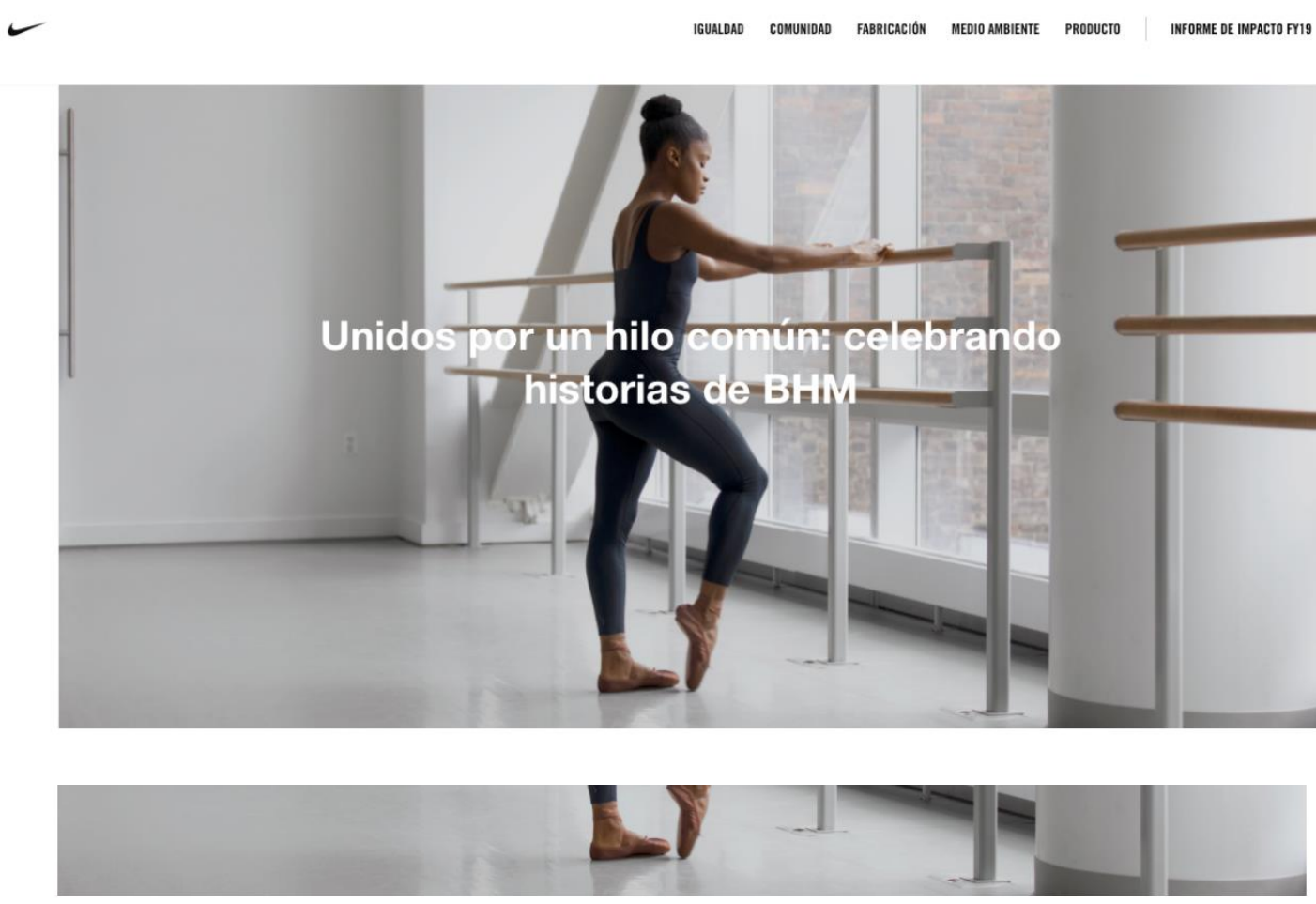

$<$ COMPARTIR

Para el Mes de la Historia Negra, Nike lanzó la campaña Watch Us Rise ... hasta que todos ganemos junto con Common Thread, una serie de cortometrajes que muestran cómo nuestras historias y experiencias se entrelazan. Celebrando una nueva vanguardia de atletas y líderes negros de todo el mundo que definen un legado colectivo a través del poder del deporte y la cultura, la serie destaca cómo la conexión entre los atletas negros de todo el mundo está uniendo comunidades y construyendo una base para que la próxima generación lidere

Narrada por Serena Williams, la primera película de la serie presenta a los atletas Ingrid Silva y Alex Thomas diciendo sus respectivas verdades y mostrando a la próxima generación lo que es posible cuando creemos que nuestras pasiones no pueden ser limitadas y que no hay barreras que nos puedan detener. Míranos levantarnos. Hasta que todos ganemos.

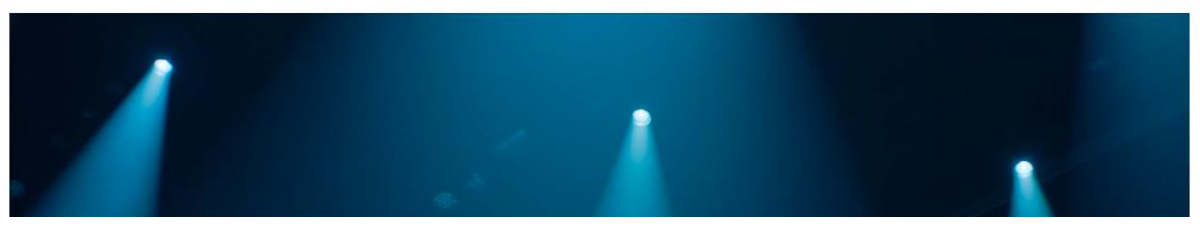

Source: https://purpose.nike.com/common-thread:

For Black History Month 2019,

Nike launched the Watch Us Rise... Until We All Win campaign alongside Common Thread, a series of short films showcasing how our stories and experiences are woven together. Celebrating a new vanguard of Black athletes and leaders around the world who define a collective legacy through the power of sport \& culture, the series highlights how the connection between 
Black athletes across the world is uniting communities and building a foundation for the next generation to lead.

Narrated by Serena Williams, the first film in the series features athletes Ingrid Silva and Alex Thomas speaking about their respective experiences and showing the next generation what is possible to achieve when we believe our passions cannot be limited, and no barriers can hold us back. Watch us rise. Until we all win.

In this transcription, the specific context in which the corporate campaign is framed becomes clear. Undoubtedly, the social objective that the brand intends to promote through the instrumentalisation of black sportsmen and women can be seen.

Despite the fact that the object of achievement of all the narratives is oriented towards building and sharing a legacy for the black athletes of the future, it is relevant to analyse the way in which each protagonist expresses it discursively from different disciplines or sporting practices. Taking figure 2 as a reference, we exemplify through three frames with the inserted transcript, the projection of the social object that is intended to be achieved in the community of black sportsmen and sportswomen. In all three examples, the sportswomen express their desire to inspire future generations. The images help us to interpret how the black sportswomen contribute through sport to the strengthening of the individual and social identity of their community.

Crystal Dunn tells part of her life experience to become a professional player and expresses some of the barriers she has faced as a person of colour. She also says how important it is for the black sports community to jointly protect a legacy for the future.

In the case of Ashlee Lawson Green, co-founder of the RunGrl Sports Club, we see the athlete practising her sporting discipline alongside peers from similar backgrounds and diverse socio-cultural origins. She states that one of the purposes of her own club is to empower and inspire the next generation.

Figure 2. Nike Instagram campaign I
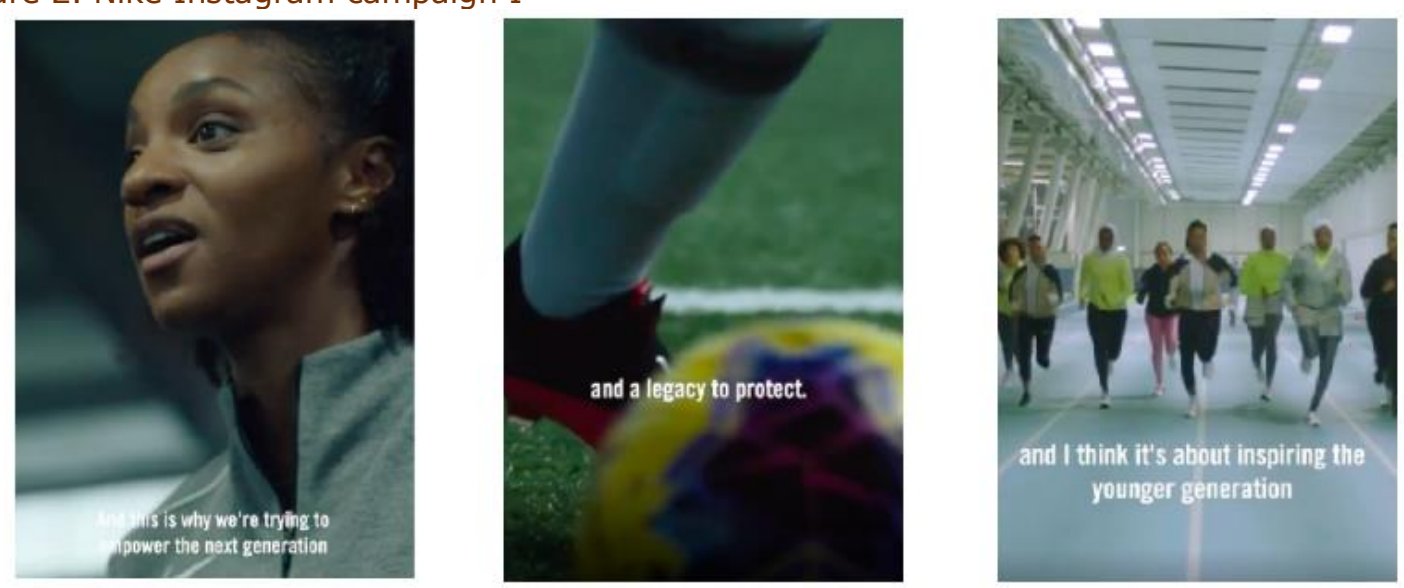

Source: Nike Instagram account (Video 2: (https://www.instagram.com/p/B81iLqrA1-b/; Video 3: https://www.instagram.com/p/B9KIOD2HHe7/ ) 
To demonstrate that the social objective of the brand is recurrent in all the campaign videos, we show a transcript of video 2 , in which the narrator says the following:

Whether the story begins in South London, where a young woman uses the power of football to bridge the gap between a new generation and the old guard.

You know, I can honestly like take a page out of you all's books.

For me, my parents moved me out to where soccer was more visible, and I just started playing.

But for you guys, you really took an initiative.

A lot of people don't do it.

And this is why we're trying to empower the next generation to take that initiative and you guys have already done that.

To go fast, we have to go together.

To lead the way, we have to lead together.

Making a future we can believe in, and a legacy to protect.

\section{Category 2. Target or set of desired facts or motivating forces: to use sport to enhance racial and ethnic equality among the present and future generations.}

The next step in our paper is to delve deeper into the motivational aspects that lead the protagonists to use sport as a driving force for social values. In the narration of Serena Williams (video 1), we identify the desire of two young dancers to make their way in the artistic discipline:

This story begins with a prodigy from Brazil, who goes from her local dance center to become the face of modern ballet. And it continues with the rising young dancer from Florida inspired by those who paved the way to uplift anyone who sees him move.

Together, they channel the beauty of motion, making space for others just like them

In the same video, dancer Ingrid calls for equal opportunities in the recruitment of dancers of colour. She also shows how motivated she is to have overcome socio-cultural barriers in her experience:

Directors have to take the first step in hiring dancers of color, so the stage looks like what the rest of the world looks like, so people can feel represented on stage. I think the greatest lesson ballet has taught me is that there is no limit to be who you want to be.

I think also as a dancer, we hear so many "no's" or "you're not good enough" or "you can't do enough", but just to be on the stage with so many people and represent something larger than ourselves, that's so fulfilling.

Similarly, the following transcript of video 2 exemplifies how professional football player Crystal relates the desired set of facts and the motivating force that mobilises two young black sportswomen located in different geographical locations. Their names are Debra Nelson and Kairaba Ali-Danbukar, and they are two young female football players. We 
can identify the importance for these sportswomen of an equal context in which to play football:

Whether the story begins in South London, where a young woman uses the power of football to bridge the gap between a new generation and the old guard.

Or in the Bronx, where a teenager can't find her team for girls her age in her borough, so she finds one on her own, traveling wherever it takes to join her pride.

Or on Long Island, with a young woman who comes back stronger than ever, representing her country and all girls who sees themselves in her when they turn on the TV.

This is a dialogue of their shared experience.

This is their common thread.

In video 3 (figure 3), audiovisual sequences are interspersed to describe the athletes' shared experience of what drives their individual and social identity:

Figure 3. Nike Instagram campaign II
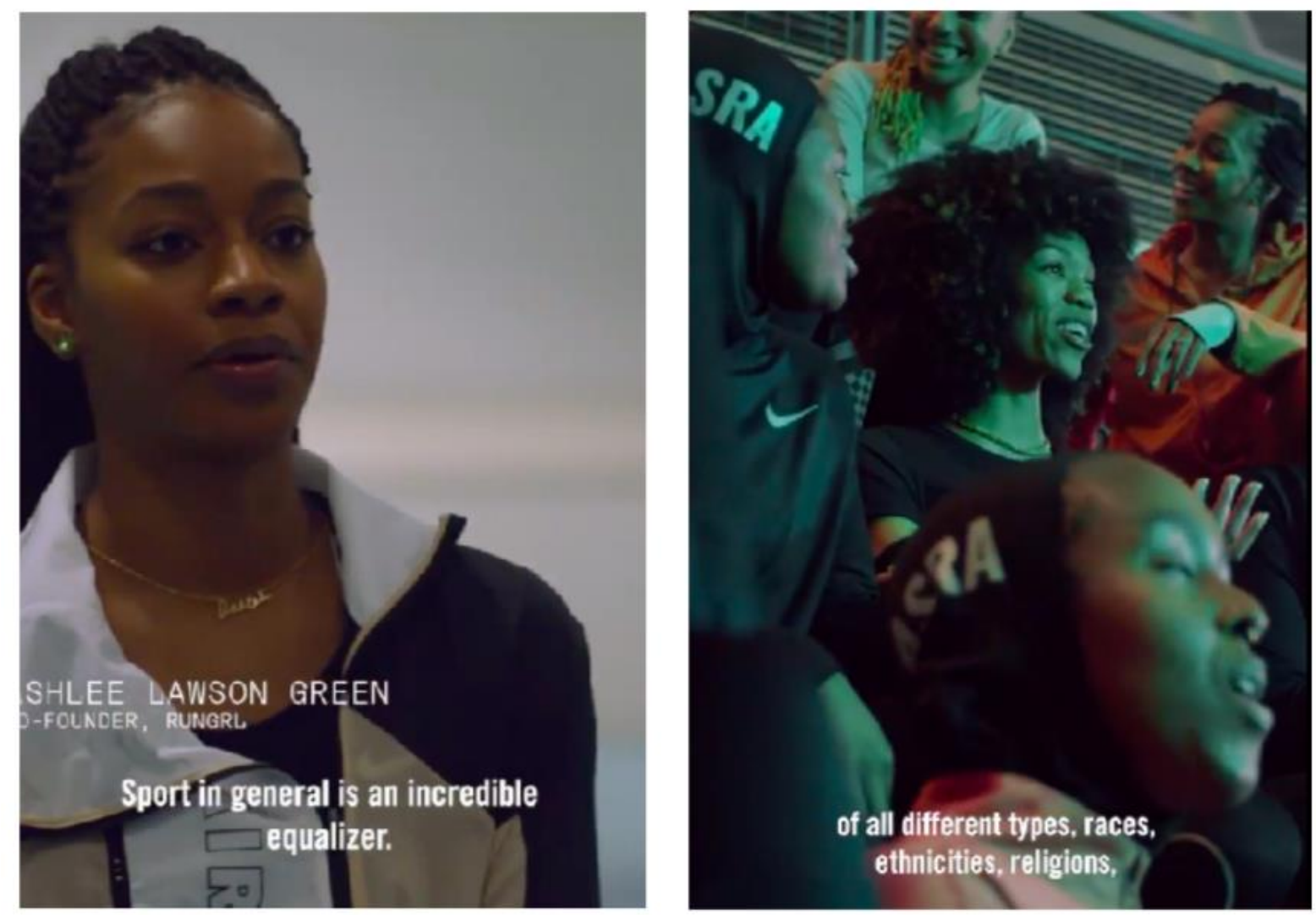

Source: Nike Instagram account. (Video 3: https://www.instagram.com/p/B9KIOD2HHe7/ )

Similarly, in video 2, Debra describes the power of football to overcome socio-cultural difficulties and to impact positively on the development of individuals and society: 
Trying to get girls to play football in like the inner city of London it's quite hard because of like my cultural stereotypes or like just safety issues, and I think providing them with a safe place to play football is the biggest thing.

Soccer is so powerful. It's fun, you're learning how to communicate, you're learning how to manage your emotions, you're learning how to build positive relationships and, I think if we want to carry on building a positive Society you have to start with the next generation, and I think football is the easiest thing to use to encourage positivity in society.

\section{Category 3: Recipient or beneficiary strengthen the black sportswomen's union.}

In this last category, we have identified a cross-cutting theme that runs through the entire narrative of the campaign: building a legacy of equality and unity for the black sports community. We felt it was important to show how the protagonists seek to spread a cultural legacy for the benefit of future generations of black athletes.

In Figure 4, female athletes (professional athlete Vashti Cunningham is the narrator of this video) show their support and desire for current black athletes to inspire each other. In these examples, we can identify how the social purpose of the campaign is directed for the direct benefit of black sports communities. In all of the narratives, there is a call for equal opportunities for black athletes from all geographic backgrounds.

In these examples, the founders of the women's athletics teams RunGrl and Asra relate the importance of encouraging the practice of their sporting disciplines together with other sportswomen from the same socio-cultural backgrounds in order to strengthen the unity of black sports communities around the world.

Figure 4. Nike Instagram campaign III
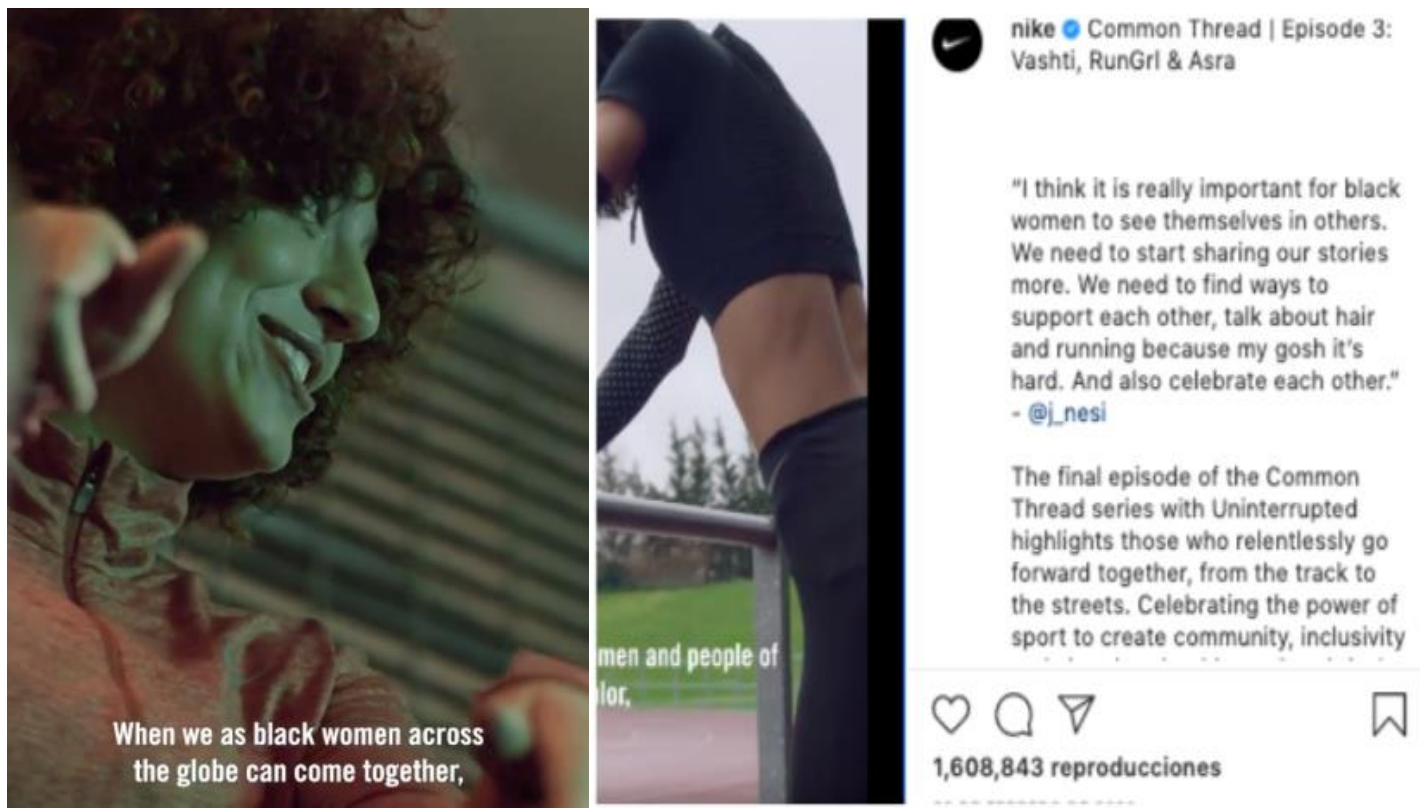

Source: Nike Instagram account. (Video 3: https://www.instagram.com/p/B9KIOD2HHe7/) 
We rely again on the transcript of video 2 to show how sportswomen are committed to achieving their goals if they stick together and unite.

You know, I can honestly like take a page out of you all's books.

For me, my parents moved me out to where soccer was more visible, and I just started playing.

But for you guys, you really took an initiative.

A lot of people don't do it.

And this is why we're trying to empower the next generation to take that initiative and you guys have already done that.

To go fast, we have to go together.

To lead the way, we have to lead together.

Making a future we can believe in,

and a legacy to protect.

\section{Conclusions and discussion.}

The results allow us to compare this study with the previous findings mentioned in the introduction. Conclusions will be shown in relation to the questions that are at the origin of the study.

The data corroborate that the Nike brand acquires a social function in the discursive and symbolic projection of socio-cultural values through the creation and distribution of the corporate campaign "Common Thread", published on its Instagram account. In relation to what has been shown in the analysed data of the three contents, it can be evidenced that the brand adopts a leading role in the construction of a specific socio-cultural symbolic field. The social objective that the brand aims to project is discursively instrumentalised through the experience of different sportsmen and celebrities. As seen in the data through the discourse analysis, the athletes promote narratives aimed at strengthening the individual and social identity of the community of black athletes from different places and geographical locations. In all cases, the data reveal motivational aspects that lead the protagonists to use sport as a promoter of fundamental rights and socio-cultural values. Moreover, underlying all three contents is a cross-cutting narrative that seeks to promote equal opportunities for young athletes, as well as to strengthen communities of athletes from different geographical, ethnic and racial backgrounds.

From this perspective, we rely on the second question to identify narrative patterns that recurrently articulate the discourse in the campaign analysed. The discursive proposal of the contents is structured through actantial elements that modulate a common narrative in the projection of specific socio-cultural values. This transversal structure helps to clearly channel the social and cultural values that the brand intends to evoke. As the audiovisual data analysed shows, all subjects (celebrities and athletes) manifest the pursuit of a common object and desire: to build and strengthen a legacy for future generations of black athletes. This object of social achievement is pursued through the forces and motivational constructs that proliferate from the practice of sport. With this perspective in mind, sport would function as a driving force for racial and ethnic equality that enables these communities to achieve a common goal for the benefit of present and future generations of sportsmen and sportswomen. 
In summary, the results of this work have shown that branding plays a determining role in using socio-cultural values in defence of equality and fundamental rights. The symbolic projection that is emitted is discursively instrumentalised through the live narratives of black athletes and celebrities who belong to different sporting disciplines and come from diverse ethnic and racial contexts.

Far from conceiving the brand phenomenon as a result in itself, the aim of this study is to delve deeper into the concept of the brand as an issuing entity and producer of discourses of a social and cultural nature. We have based our research on various theoretical approaches that have studied the communicative function of corporate brands from different disciplines of the social sciences: psychology, sociology, anthropology and linguistics. However, in this case, we have been mainly approached our object of study from the semiotic nature of the discourse of the brand. This fact has helped us to elucidate the abstract conception of the brand phenomenon as a concrete and defined discursive utterance.

The main strategy of this research has been based on revealing the social function played by the discourses created and distributed by a given corporate brand. From this perspective, our questions have focused especially on identifying and describing the role that a corporate brand plays as a discursive emitter of values of a social and cultural nature. In this context, we hope that this contribution will allow us to develop this line of research from other perspectives and academic disciplines. Similarly, we hope that this study will serve to raise new questions aimed at identifying the impact on audiences of the creation of digital content that projects specific symbolic fields.

In relation to this context, we propose to discuss and delve deeper into the function that sports celebrities exercise in these contexts. In our view, it is relevant how sports celebrities become "signs", embedded semiotic systems with axiological meanings to be read and actively interpreted by their audiences. In this vein, we argue that celebrities are interpreted as texts that are discursively constructed. The meanings they generate are the product of a "structured polysemy". This refers to the multiplicity of meanings and affects they embody, as well as the intention to structure them in such a way that some meanings are foregrounded, while others are masked or displaced.

Therefore, through the analysis of the "Common Thread" campaign, we propose to highlight the productive social function of sports celebrities through the social instrumentalisation of values that enhance equality and fundamental rights, which, in turn, act in the social construction of the communities within which many of us live. This approach responds to what various authors think of as "real emotional attachments" to figures we only know through their media representations.

In this line, the results have allowed us to interpret the socio-cultural context where the athletes' narratives are developed. In relation to this context, sports celebrities become a "place" for the elaboration and construction of individual and social identity in the community of black athletes. At first, a celebrity is perceived as a legitimate source of information, as an important social process, through which relationships, identity and social and cultural norms are shared. Its expansion through media content has embedded celebrities in processes of social and personal identity formation. 
Therefore, it is suggested that the mediatised sports celebrity operates at the very heart of culture, as it resonates with conceptions of individuality, which are the ideological foundation of Western culture. If we support our argument on the postulate proposed by Marshall (1997) in relation to celebrity, then sports celebrities could play a crucial ideological function in the instrumentalisation of the discourses created and distributed by a corporate brand.

This perspective helps us to discuss how corporate communication processes are shaped in the construction of certain symbolic fields. The types of messages that the celebrity passes on to the public are semiotic elements that shape individual identification, social identity and the universality of values through a given universe of signification.

\section{References}

Aaker, D.A. (2014). Aaker on Branding. New York: Morgan James Publishing.

Agrawal, J., \& Kamakura, W. A. (1995). The Economic Worth of Celebrity Endorsers: An Event Study Analysis. Journal of Marketing, (59) 3, 56-62.

Baudillard, J. (1976). La génesis ideológica de las necesidades. Barcelona: Anagrama.

Bocock, R. (1995). El consumo. Madrid: Talasa.

Choi, S. M., \& Rifon, N. J., (2007). Who is the celebrity in advertising? Understanding dimensions of celebrity images. Journal of Popular Culture, 40(2), 304-324.

Duffett, M. (2013). Understanding Fandom: An introduction to the study of media fan culture. London: Continuum Publishing.

Dyer, G. (1988). Advertising as communication. London: Routledge.

Elliot, R., \& Wattanasuwan, K. (1998). Brand as symbolic resources for the construction of identity. International Journal of Advertising, 17(2), 131-144.

Erdogan, B.Z. (1999). Celebrity endorsement: A literature review. Journal of Marketing Management, 15 (4), 291- 315.

Gee, J.P. (2014). Una introducción al análisis del discurso: teoría y método. New York: Routledge

Giles, D. C., \& Maltby, J. (2004). The role of media figures in adolescent development: relations between autonomy, attachment, and interest in celebrities. Personality and Individual differences, 36 (4), 813-822.

Greimas, A.J. (1976). Sémiotique et sciences sociales. Paris: Éditions du Seuil.

Hinton, S., \& Hjorth, L. (2013). Understanding social media. Los Angeles: SAGE.

Hirsch, A. (1998). México: valores nacionales. Visión panorámica sobre las investigaciones de valores nacionales. México: Gernika.

Holbrook, M.B. (2001). The Chain of Effects From Brand Trust and Brand Affect to Brand Performance: The Role of Brand Loyalty. Journal of marketing, 65(2), 81-93. 
Krippendorff, K. (2013). Content analysis: an introduction to its methodology (3rd ed.). London: SAGE.

Lacasa, P., Méndez, L., \& Martínez, R, (2013). Studies in media and communication, Redfame publishing.

López de Ayala, M. C. (2004). El análisis sociológico del consumo: una revisión histórica de sus desarrollos teóricos. Sociológica. Revista de pensamiento social, 5, 161-188.

Marshall, P.D. (1997). Celebrity and Power. Fame in Contemporary Culture. Minneapolis: University of Minnesota Press.

McCracken, G. (1986). Culture and Consumption: A Theoretical Account of the Structure and Movement of the Cultural Meaning of Consumer Goods. Journal of Consumer Research, 13 (1), 71-84.

McCracken, G. (1989). Who is the Celebrity Endorser? Cultural Foundation of the Endorsement Process. Journal of Consumer Research, 16 (3), 310-321.

Neuendorf, K.A. (2002). The Content Analysis Guidebook. London: Sage Publications.

Pringle, H. (2004). Celebrity Sells. Chichester: John Wiley \& Sons.

Semprini, A. (1995). El marketing de la marca: una aproximación de la marca. Barcelona: Paidos Iberica Ediciones.

Silvera, D. H. \& Austad, B. (2004). Factors predicting the effectiveness of celebrity. Endorsement advertisements. European Journal of Marketing, 38 (11/12), 1509-1526.

Solomon, M. R., Bamossy, G., \& Askegaard, S. (1999) Consumer behavior: a European perspective. Harlow: Financial Times Prentice Hall.

Turner, G. (2004). Understanding Celebrity. London, SAGE.

Verplanken, B., \& Holland, R. (2002). Motivated Decision Making: Effects of Activation and Self Centrality of Values on Choices and Behavior. Journal of Personality and Social Psychology, 82, 432-447. 